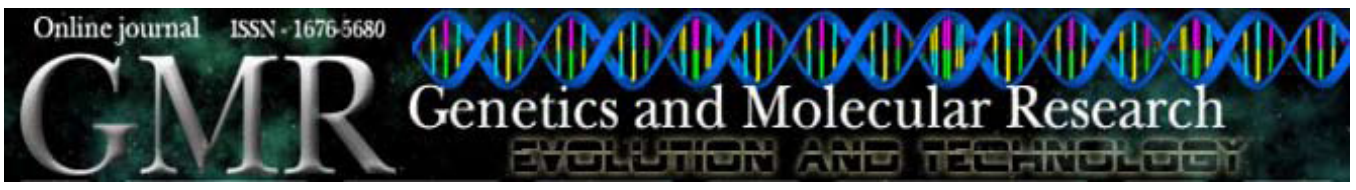

\title{
Africanized honey bees more efficiently convert protein diets into hemolymph protein than do Carniolan bees (Apis mellifera carnica)
}

\author{
F.A. Cappelari ${ }^{1}$, A.P. Turcatto ${ }^{1}$, M.M. Morais ${ }^{1}$ and D. De Jong ${ }^{2}$ \\ ${ }^{1}$ Departamento de Biologia, Faculdade de Filosofia, \\ Ciências e Letras de Ribeirão Preto, \\ Universidade de São Paulo, Ribeirão Preto, SP, Brasil \\ ${ }^{2}$ Departamento de Genética, Faculdade de Medicina, \\ Universidade de São Paulo, Ribeirão Preto, SP, Brasil
}

Corresponding author: F.A. Cappelari

E-mail: facappelari@usp.br

Genet. Mol. Res. 8 (4): 1245-1249 (2009)

Received May 20, 2009

Accepted August 10, 2009

Published October 13, 2009

\begin{abstract}
The superiority of Africanized over European honey bees in tropical and subtropical regions of the New World is both well documented and poorly understood. As part of an effort to try to understand the process by which the displacement of European bees occurred, we examined the ability of these two types of bees and of hybrids between the two to convert natural and artificial diets into usable protein. Newly emerged bees from colonies of tropically adapted Africanized and temperate-origin Carniolan bees and firstgeneration hybrids between the two were caged and fed artificial and natural protein diets for six days to determine whether there were differences in their ability to use these diets. The Africanized bees developed significantly higher protein levels in the hemolymph
\end{abstract}


than did the Carniolan bees. The difference was $31 \%$ when the bees were fed bee bread (37.5 and $28.56 \mu \mathrm{g}$ protein $/ \mu \mathrm{L}$ hemolymph, respectively). The hybrids developed protein levels intermediate between the two parental types. These were approximately 10 times the levels found in bees fed with sucrose alone. Superior food conversion efficiency of the Africanized bees may be one of the reasons for their superiority both in the wild and for beekeeping in tropical and subtropical Latin America.

Key words: Apis mellifera; Africanized; Protein diets; Bradford; Bee nutrition

\section{INTRODUCTION}

The Africanized honey bee, a predominantly African polyhybrid resulting from a mixture of European subspecies already present in Brazil, Apis mellifera mellifera, A. m. lingustica, A. m. caucasica, and A. m. carnica and the African bee A. m. scutellata (Francoy et al., 2009), has been highly successful in dominating tropical and subtropical regions of the New World. Arias and Sheppard (1996) placed the Africanized bee in the same phylogenetic branch as the African subspecies. Its strong defensive capability, its ability to live in environments that are inhospitable and its shorter development time are characteristics of the Africanized honey bee that make it similar to the African bee.

These characteristics allowed Africanized bees to rapidly multiply, dominate and replace the European honey bee that existed in Brazil until the late 1950s (Gonçalves, 1974). Other characteristics that contributed to the dominance of Africanized bees over European bees throughout most of South America include more efficient pollen collection (Couto, 1998); more efficient communication (Nuñes, 1979); more highly developed defensive behavior (Stort and Gonçalves, 1991; Guzmán-Novoa et al., 2002); more intense swarming behavior (Winston et al., 1979; Otis, 1980), and resistance to the parasitic mite Varroa destructor (De Jong and Gonçalves, 1998; Marques et al., 2002; Moretto, 2002).

According to Roubik (1980), a combination of various factors makes Africanized honey bees superior in their competition with other types of honey bees, especially in their exploitation of compact and rich food sources, such as larger body size, larger colony size and superior capability to recruit to new food sources. Africanized honey bees have a metabolic rate intermediate between those of African and European races, which is evident in their flight physiology (Harrison et al., 2005). Metabolic rate can also be used to evaluate the defensive behavior of Africanized honey bees (Andere et al., 2002). The highly defensive behavior of Africanized honey bees also involves an inherent increase in the respiratory rate; however, it is not known whether this increase is relevant to their behavioral response (Southwick et al., 1990).

Food metabolism plays a fundamental role in bee biology (Standifer et al., 1977). The digestive process influences the body composition of the bees, including the percentages of glycogen, lipids and proteins (Hrassnigg and Crailsheim, 2005). The food source of the bees has been found to affect hemolymph composition (Bounias and Morgan, 1990; Cremonez et al., 1998). Various studies have been made to develop ideal protein diet for- 
mulations and observe their effect on honey bee physiology (Herbert, 1992; Cremonez et al., 1998). Studies of the effects of protein diets have also been made with social stingless bees in Brazil (Zucoloto, 1975; Camargo, 1976; Fernandes-da-Silva and Zucoloto, 1990; Nogueira-Neto, 1997). We compared the efficiency of protein diet conversion in Africanized and European honey bees reared under the same conditions.

\section{MATERIAL AND METHODS}

Africanized honey bees were obtained from colonies of the University of São Paulo apiary in Ribeirão Preto, SP, Brazil. Carniolan bees were obtained from colonies headed by mated queens imported from Germany, provided by Peter Rosenkranz of the Hohenheim Institut fur Bienkunde. Hybrids between the two were provided by open-mating Carniolan virgin queens with Africanized drones in the Ribeirão Preto apiary. Brood combs with emerging bees were maintained in an incubator overnight and groups of 100 bees placed in wooden-hoarding cages $(11 \times 13 \times 8 \mathrm{~cm})$ with one glass wall and a metal screen bottom. The recently emerged bees from two colonies of each type of bee were pooled and mixed to populate the hoarding cages.

Five diets were tested on Africanized, Carniolan and first-generation hybrids between the two (two cage repetitions each). These diets consisted of 1 ) a non-protein control; 2) $50 \%$ bee bread (bee-fermented pollen freshly collected from brood combs) mixed with $50 \%$ powdered sucrose (by weight), with enough water to make a paste; 3) $50 \%$ soybean meal and 50\% sugar-cane alcohol yeast; 4) sugar-cane alcohol yeast alone, and 5) honey (very low protein control). All caged bees had free access to $50 \%$ (by weight) sucrose syrup.

On day 0 and six days after placing the recently emerged bees in the hoarding cages, protein levels in the hemolymph were determined using the Bradford (1976) method modified by Cremonez et al., 1998. Two pools of hemolymph from five bees each were collected from each cage and two cages were set up for each type of bee and each diet. Statistical analysis was made with SigmaStat (3.1), using the Student $t$-test for comparing two groups and a one-way ANOVA for comparing three groups. The corresponding non-parametric tests, Smirnov-Kolmogorov and Kruskal-Wallis, were used when the data distributions departed from normality. Post hoc comparisons were made with the Tukey test after one-way ANOVA, and the Dunn test after the Kruskal-Wallis test. The alpha level was set at $5 \%$.

\section{RESULTS AND DISCUSSION}

The protein levels in the caged bees declined significantly from 0 to 6 days of age when fed with non-protein diets and increased significantly in the bees fed the protein diets (Table 1). Africanized bees developed significantly higher protein levels in the hemolymph than did Carniolan bees fed the same diets (Table 1). Africanized bees were superior to Carniolan bees for all diets. The hybrid bees had hemolymph protein levels intermediate between the two, except for the tests made with the yeast-only diet, with which the hybrid bees had the highest protein levels. The best diet was bee bread, followed by soybean meal, and yeast, and then yeast alone. 
Table 1. Mean ( \pm standard deviation) protein concentrations in the hemolymph (in $\mu \mathrm{g} / \mu \mathrm{L}$ ) of worker honey bees (Africanized, Carniolan and hybrids between the two) confined in hoarding cages and fed for six days with five different diets.

\begin{tabular}{lccc}
\hline & Africanized & Hybrid & Carniolan \\
\hline Recently emerged & $7.64 \pm 0.06 \mathrm{a}$ & $7.14 \pm 0.04 \mathrm{~b}$ & $6.96 \pm 0.02 \mathrm{c}$ \\
Sucrose & $3.49 \pm 0.09 \mathrm{a}$ & $3.09 \pm 0.05 \mathrm{~b}$ & $3.06 \pm 0.09 \mathrm{~b}$ \\
Bee bread and sucrose & $37.5 \pm 0.64 \mathrm{a}$ & $36.7 \pm 0.37 \mathrm{~b}$ & $28.6 \pm 0.21 \mathrm{c}$ \\
Soybean meal and yeast & $25.9 \pm 0.23 \mathrm{a}$ & $22.8 \pm 0.09 \mathrm{~b}$ & $21.3 \pm 0.07 \mathrm{~b}$ \\
Yeast & $22.3 \pm 0.06 \mathrm{~b}$ & $29.8 \pm 0.09 \mathrm{a}$ & $19.0 \pm 0.06 \mathrm{~b}$ \\
Honey & $4.68 \pm 0.06 \mathrm{a}$ & $4.09 \pm 0.02 \mathrm{~b}$ & $3.67 \pm 0.03 \mathrm{c}$ \\
\hline
\end{tabular}

All caged bees had free access to sucrose syrup. Means followed by different letters in the same row are significantly different.

Under the same conditions, the Africanized bees had better protein conversion of the diets than did the Carniolan and hybrid bees. The Africanized bees had 31\% more protein than the (European) Carniolan bees when fed the natural diet (bee bread; Table 1). Even when fed sucrose alone, the protein levels of the Africanized bees were 14\% higher (Table 1).

Other studies have also pointed to metabolic differences between honey bee races (Harrison and Hall, 1993; Harrison et al., 2005). Zakaria (2007) found significant differences in hemolymph protein levels among the honey bee species, A. m. lamarckii, A. m. carnica and A. m. lingustica; A. m. lamarckii had the highest levels, followed by A. m. carnica and A. m. lingustica. The concentration of acid phosphatase was also highest in A. m. lamarckii.

The dominance of Africanized honey bees over European bees in Brazil is evident from studies using morphometrics (Francoy et al., 2006) and molecular markers to determine the type of bee in the wild and in apiaries (Sheppard et al., 1991; Rotta, 1999; Guzmán-Novoa et al., 2002; Diniz et al., 2003; Collet et al., 2006). More efficient use of protein diets could be one of the contributing factors for this ecological dominance (Southwick et al., 1990).

\section{ACKNOWLEDGMENTS}

We thank Adelino Penatti, Marcela A.F. Bezerra-Laure, and Vera Lucia Figueiredo for technical assistance, and Rodrigo Pires Dallacqua, and Juliana Ramos Martins for helping with the protein analyses. We also thank Tiago Mauricio Francoy for his help with the statistical analyses and discussions concerning the research. The Brazilian agencies CNPq and FAPESP (\#2007/07701-3) provided financial assistance. Publication supported by FAEPAHC-FMRP-USP.

\section{REFERENCES}

Andere C, Palacio MA, Rodriguez EM, Figini E, et al. (2002). Evaluation of the defensive behavior of two honeybee ecotypes using a laboratory test. Genet. Mol. Biol. 25: 57-60.

Arias MC and Sheppard WS (1996). Molecular phylogenetics of honey bee subspecies (Apis mellifera L.) inferred from mitochondrial DNA sequence. Mol. Phylogenet. Evol. 5: 557-566.

Bounias M and Morgan MRJ (1990). Effect of sucrose feeding on the induction of honey bee hemolymph alpha glucosidase. J. Apic. Res. 29: 181-186.

Bradford MM (1976). A rapid and sensitive method for the quantitation of microgram quantities of protein utilizing the principle of protein-dye binding. Ann. Biochem. 72: 248-254. 
Camargo CA (1976). Dieta semi-artificial para abelhas da subfamília Meliponinae (Hymenoptera, Apidae). Ciênc. Cult. 28: $430-431$.

Collet T, Ferreira KM, Arias MC, Soares AE, et al. (2006). Genetic structure of Africanized honeybee populations (Apis mellifera L.) from Brazil and Uruguay viewed through mitochondrial DNA COI-COII patterns. Heredity 97: 329-335.

Couto LA (1998). Nutrição de abelhas. In: Anais do $12{ }^{\circ}$ Congresso Brasileiro de Apicultura, Salvador.

Cremonez T, De Jong D and Bittondi M (1998). Quantification of hemolymph proteins as a fast method for testing protein diets for honey bees (Hymenoptera: Apidae). J. Econ. Entomol. 91: 1284-1289.

De Jong D and Gonçalves LS (1998). The Africanized Bees of Brazil have become tolerant to Varroa. Apiacta 33: 65-70.

Diniz NM, Soares AEE, Sheppard WS and Del Lama MA (2003). Genetic structure of honeybee populations from southern Brazil and Uruguay. Genet. Mol. Biol. 26: 47-52.

Fernandes-da-Silva PG and Zucoloto FS (1990). A semi-artificial diet for Scaptotrigona depilis. J. Apicult. Res. 29: 233-235.

Francoy TM, Prado PRR, Gonçalves LS, Costa LF, et al. (2006). Morphometric differences in a single wing cell can discriminate Apis mellifera racial types. Apidologie 37: 91-97.

Francoy TM, Wittmann D, Steinhage V, Drauschke M, et al. (2009). Morphometric and genetic changes in a population of Apis mellifera after 34 years of Africanization. Genet. Mol. Res. 8: 709-717.

Gilliam M and Shimanuki H (1971). Blood cells of the worker honey bee. J. Apic. Res. 10: 79-85.

Gonçalves LS (1974). The introduction of the African bees (Apis mellifera adansonii) into Brazil and some comments on their spread in South America. Am. Bee J. 114: 414-419.

Guzmán-Novoa E, Hunt GJ, Uribe JL, Smith C, et al. (2002). Confirmation of QTL effects and evidence of genetic dominance of honeybee defensive behavior: results of colony and individual behavioral assays. Behav. Genet. 32: 95-102.

Harrison JF and Hall HG (1993). African-European honeybee hybrids have low nonintermediate metabolic capacities. Nature 363: 258-260.

Harrison JF, Taylor OR Jr and Hall HG (2005). The flight physiology of reproductives of Africanized, European, and hybrid honeybees (Apis mellifera). Physiol. Biochem. Zool. 78: 153-162.

Herbert EW (1992). Honey Bee Nutrition. In: The Hive and the Honey Bee (Graham JM, ed.). Dadant, Hamilton, 197-233.

Hrassnigg N and Crailsheim K (2005). Differences in drone and worker physiology in honeybees (Apis mellifera). Apidologie 36: 255-277.

Marques MHC, De Jong D, Rosenkranz P and Gonçalvez LS (2002). Varroa-tolerant Italian honey bees introduced from Brazil were not more efficient in defending themselves against the mite Varroa destructor than Carniolan bees in Germany. Genet. Mol. Res. 1: 153-158.

Moretto G (2002). Mortality of Varroa destructor in broodless Africanized and Carnica honey bee (Apis mellifera L.) colonies. Interciencia 27: 702-704.

Nogueira-Neto P (1997). Vida e Criação de Abelhas Indígenas sem Ferrão. Editora Nogueirapis, São Paulo.

Nuñes JA (1979). Time spent on various components of foranging activity: comparison beetween European and Africanized honeybee in Brazil. J. Apic. Res. 18: 110-115.

Otis GW (1980). The swarming biology and population dynamics of the Africanized honey bee. Ph.D. dissertation, University of Kansas, Lawrence.

Rotta IT (1999). Análise aloenzimática, morfométrica e dos padrões do DNA mitocondrial das abelhas Africanizadas do Brasil. Doctoral thesis, Universidade Federal de São Carlos, São Carlos.

Roubik DW (1980). Foraging behavior of competing Africanized honey bees and stingless bees. Ecology 61: 836-845.

Sheppard WS, Soares AEE, De Jong D and Shimanuki H (1991). Hybrid status of honey bee populations near the historic origin of Africanization in Brazil. Apidologie 22: 643-652.

Southwick EE, Roubik DW and Williams JM (1990). Comparative energy balance in groups of Africanized and European honey bees: ecological implications. Comp. Biochem. Physiol. A Physiol. 97: 1-7.

Standifer LN, Moeller FE, Kauffeld NM, Hebert Jr EW, et al. (1977). Supplemental feeding of honey bee colonies. United States Department of Agriculture. Information Bulletin, 413-418.

Stort AC and Gonçalves LS (1991). Genetics of Defensive Behavior. II. In: The "African” Honey Bee (Spivak M, Fletcher JDC and Breed MD, eds.). Westview Press, Boulder, 329-356.

Winston ML, Otis GW and Taylor OR (1979). Absconding behavior of the Africanized honey bee in South America. $J$. Apic. Res. 18: 85-94.

Zakaria ME (2007). Factors affecting on the food metabolism in some honey bee races. J. Appl. Sci. Res. 3: 311-316.

Zucoloto FS (1975). Valor nutritivo de pólens usados por diferentes espécies de abelhas para Nannotrigona (Scaptotrigona) postica (Hymenoptera, Apoidea). Rev. Bras. Biol. 35: 77-82. 